\title{
An Umbrella Review of Systematic Reviews and Meta-Analyses Evaluating the Success Rate of Prosthetic Restorations on Endodontically Treated Teeth
}

\author{
Amirhossein Fathi (iD, ${ }^{1}$ Behnaz Ebadian, ${ }^{2}$ Sara Nasrollahi Dezaki, ${ }^{3}$ Nahal Mardasi, \\ Ramin Mosharraf, ${ }^{1}$ Sabire Isler, ${ }^{5}$ and Shiva Sadat Tabatabaei ${ }^{3}$ \\ ${ }^{1}$ Department of Prosthodontics, Dental Materials Research Center, Dental Research Institute, School of Dentistry, \\ Isfahan University of Medical Sciences, Isfahan, Iran \\ ${ }^{2}$ Dental Implants Research Center, Department of Prosthodontics, School of Dentistry, Isfahan University of Medical Sciences, \\ Isfahan, Iran \\ ${ }^{3}$ Dental Students' Research Committee, School of Dentistry, Isfahan University of Medical Sciences, Isfahan, Iran \\ ${ }^{4}$ Department of Prosthodontics, Ahvaz Jundishapur University of Medical Sciences, Ahvaz, Iran \\ ${ }^{5}$ Department of Prosthodontics, Faculty of Dentistry, Istanbul University, Istanbul, Turkey
}

Correspondence should be addressed to Amirhossein Fathi; amir_alty@yahoo.com

Received 5 December 2021; Revised 20 January 2022; Accepted 3 February 2022; Published 22 February 2022

Academic Editor: Stefano Pagano

Copyright (C) 2022 Amirhossein Fathi et al. This is an open access article distributed under the Creative Commons Attribution License, which permits unrestricted use, distribution, and reproduction in any medium, provided the original work is properly cited.

\begin{abstract}
Statement of the Problem. Various direct and prosthetic restorations are clinically used to restore endodontically treated teeth. However, determining the most successful and reliable treatment to restore endodontically treated teeth is affected by numerous elements and still unclear for most clinicians. Therefore, this umbrella review study assessed the systematic/meta-analytic reviews (S/M-R) regarding the success rate of prosthetic restorations in endodontically treated teeth. Materials and Methods. The electronic search was conducted in the MEDLINE/PubMed, Cochrane, and Google Scholar databases until November 2020, regardless of language limitations. The inclusion criterion was as follows: S/M-R regarding prosthetic restorations in endodontically treated teeth. Three qualified researchers evaluated the inclusion criteria and bias risk. The fourth investigator was referred to when facing any doubtfulness. Results. From 43 achieved S/M-R, 14 studies were selected for this inquiry. Primary extracted information included success rate, survival rate, and postendodontic failure rate. Five S/M-R had a moderate risk of bias, and nine S/M-R had a low risk of bias and were considered strong clinical evidence in this examination. According to the low-risk reports, the success rate of fiber posts was higher than that of metal posts; the rate of root fracture in metallic and fiber posts was alike; the failure rate for fiber posts was comparable to fixed partial dentures or single crowns; the construction of endocrowns was likely to perform better than intracanal posts, composite resin, or inlay/onlay restorations. Conclusion. It appears that with practice and experience, deciding which type of restoration to choose changes. In dental restorations associated with root canal therapy, the single crowns are likely to be a proper option. Nevertheless, due to the heterogeneity of the studies, more clinical assessments are required to achieve more specific findings in this field.
\end{abstract}

\section{Introduction}

Endodontic therapy is a routine and standard dental treatment [1-7]. Through endodontic therapy, tooth material is unavoidably sacrificed, and the tooth is weakened $[8,9]$. It is thereby apparent that ET teeth require restoration
$[10,11]$. Determining the proper restoration for an endodontically treated tooth is associated with the number of vital teeth, anatomical situation, occlusal pressure, and restorative and aesthetic necessities of the tooth [12]. In general, benefits can be achieved through both traditional direct restorations and prosthetic restorations such as 
crowns, fixed partial dentures, removable partial dentures, and mixed removable-fixed prostheses, with or without postplacement.

The application of posts has been widely discussed in dentistry for a long time, and they are commonly suggested when the amount of remaining hard tissue is crucial $[13,14]$. Popular postsystems consist of both cast and prefabricated posts with a broad order of substances. The use of different posts requires applying particular principles [15]. Recently, fiber-reinforced posts have been introduced in addition to traditional metal posts to preserve teeth with a small amount of residual structure. Since mechanical properties of the whole system, including post, cement, and dentine should be homogenous, engaging in fiber posts cemented and reconstructed by composite resin material is likely to ensure a good performance [16].

When it is impossible to use implants, removable or fixed dentures, restoring ET teeth is more critical. The results of a systematic examination [17] showed that the retention, satisfaction, and cost-effectiveness of restored teeth with a single crown or implant are higher than fixed or removable dentures. However, other systematic studies have found no significant difference between the survival rate of restored ET teeth with single crowns and implants [18].

Based on several current systematic reviews [19], endodontically treated (ET) teeth present a predicted survival rate of $87 \%$ within eight to ten years. Researchers evaluated cases of monitoring teeth after both first endodontic therapy and retreatment, excluding periapical surgery treatments. Different epidemic-related studies [20], where a substantial cohort was examined (over one million cases), obtained a survival rate of $97 \%$ in ET teeth after eight years.

One of the most influential and determining factors for the success of endodontic therapy is whether a periapical injury exists former to practice [21-25]. Other circumscribing parameters contain the amount of the root filling in association with the root crown [22-24, 26], pulp status before therapy $[23,24]$, postendodontic coronal restoration $[20,25,27,28]$, and proximal contacts [19]. It is assumed that molars exhibit significantly lower survival rates than other teeth; this theory has been confirmed by former cohort investigations $[29,30]$. Others have been incapable of notably relating particular teeth to the durability of treatment [31]. More elements have also been examined in previous reports. However, confirmation of their influence on the survival rate of ET teeth is weak or uncertain. These factors include age [24, 25,31], the kind of post [32-35], root filling mass $[24,27]$, and the number of sessions until the end of endodontic therapy $[36,37]$.

Despite the abundance of S/M-R in this area, a lack of consensus is seen among specialists $[38,39]$ and information gaps cause failures in clinical practice. Therefore, valid scientific documentation is required to make a proper decision. Considering the lack of compliance among studies on a particular technique or methodology and since scientific studies require impartiality, Cochrane proposed a new kind of study called the $\mathrm{S} / \mathrm{M}$ review, in which findings from multiple S/M-R are combined into one text to increase confidence in decision-making by comparing scientific data
TABLe 1: PICO strategy.

\begin{tabular}{lc}
\hline PICO inquiry & Description \\
\hline Population & Teeth receiving root canal treatments \\
Intervention & Restoring endodontically treated teeth \\
Comparison & No comparison was determined \\
Outcome & Survival rate and failure rate of restored ET teeth \\
\hline
\end{tabular}

$[40,41]$. The purpose of this overview was to find S/M-R determining ET teeth restoration success and evaluate the quality level of studies on the success of ET teeth treatment methods.

\section{Materials and Methods}

2.1. Search Strategy. Electronic search was conducted in PubMed/MEDLINE, Cochrane, and Google scholar databases until November 2020 without language limitation. The research included S/M-R and their references that examined the success of prosthetic procedures in ET teeth.

The PICO inquiry (population, intervention, comparison, and the outcome) was followed. The population included teeth that have received root canal treatments. The intervention was providing restorations for ET teeth. There was no control; hence, no comparison was performed. The outcome contained the survival rate and failure rate of restored ET teeth (Table 1).

This review study was conducted using the guidance on preferred reporting elements for systematic reviews and meta-analyses [42]. The AMSAR2 [43] method was also used for calculating the risk of S/M-R bias. Selected keywords included "prosthetic restorations" and "endodontically treated teeth."

Inclusion and exclusion criteria in S/M-R screening.

Inclusion criteria were as follows:

(1) S/M-R studies

(2) Studies in English language only

(3) Evaluating the success/failure rate of prosthetic restorations in endodontically treated teeth.

Exclusion criteria included duplicate reviews, comments, and editorials.

Full texts of studies that met our inclusion criteria were received, and these studies were considered eligible for our study.

2.2. Data Collection Process. The data were collected by three independent researchers who had already received adequate training in this field (kappa $=1.0)$. Required information such as prosthesis type, success, and survival rate was extracted from each systematic study. If there were any inconsistencies or ambiguities, the matter was resolved through discussion. If the issue was not resolved, the fourth investigator was asked to provide assistance.

2.3. Bias Risk Assessment. Based on the risk of bias assessment [43], 16 questions were used to evaluate the quality and bias of the S/M-R (Table 2). In the end, each article received a 


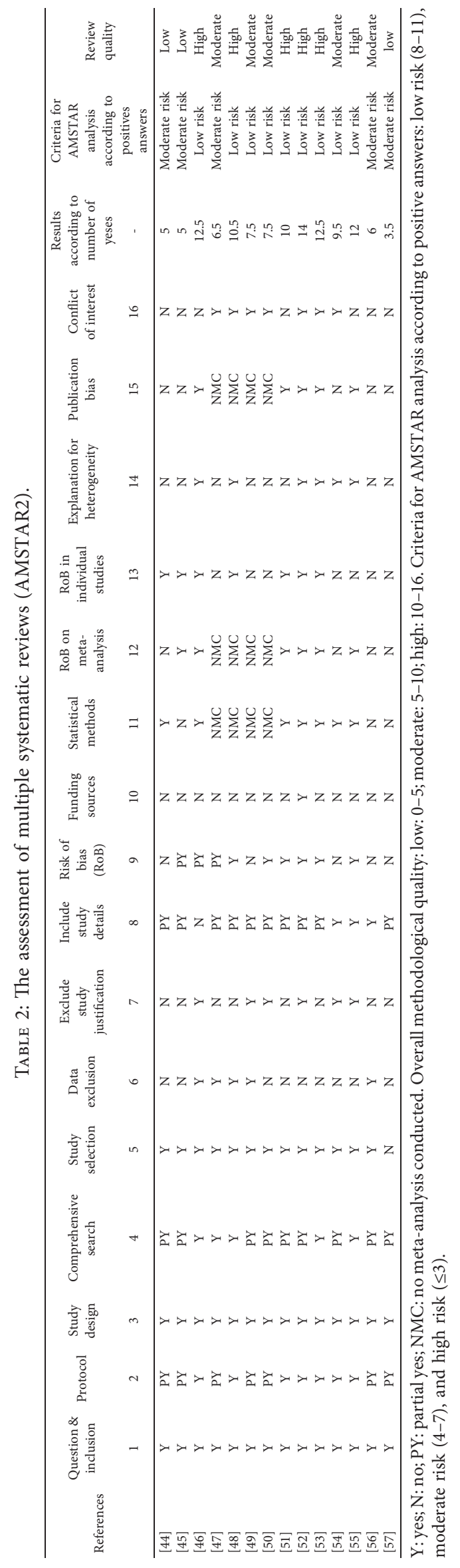




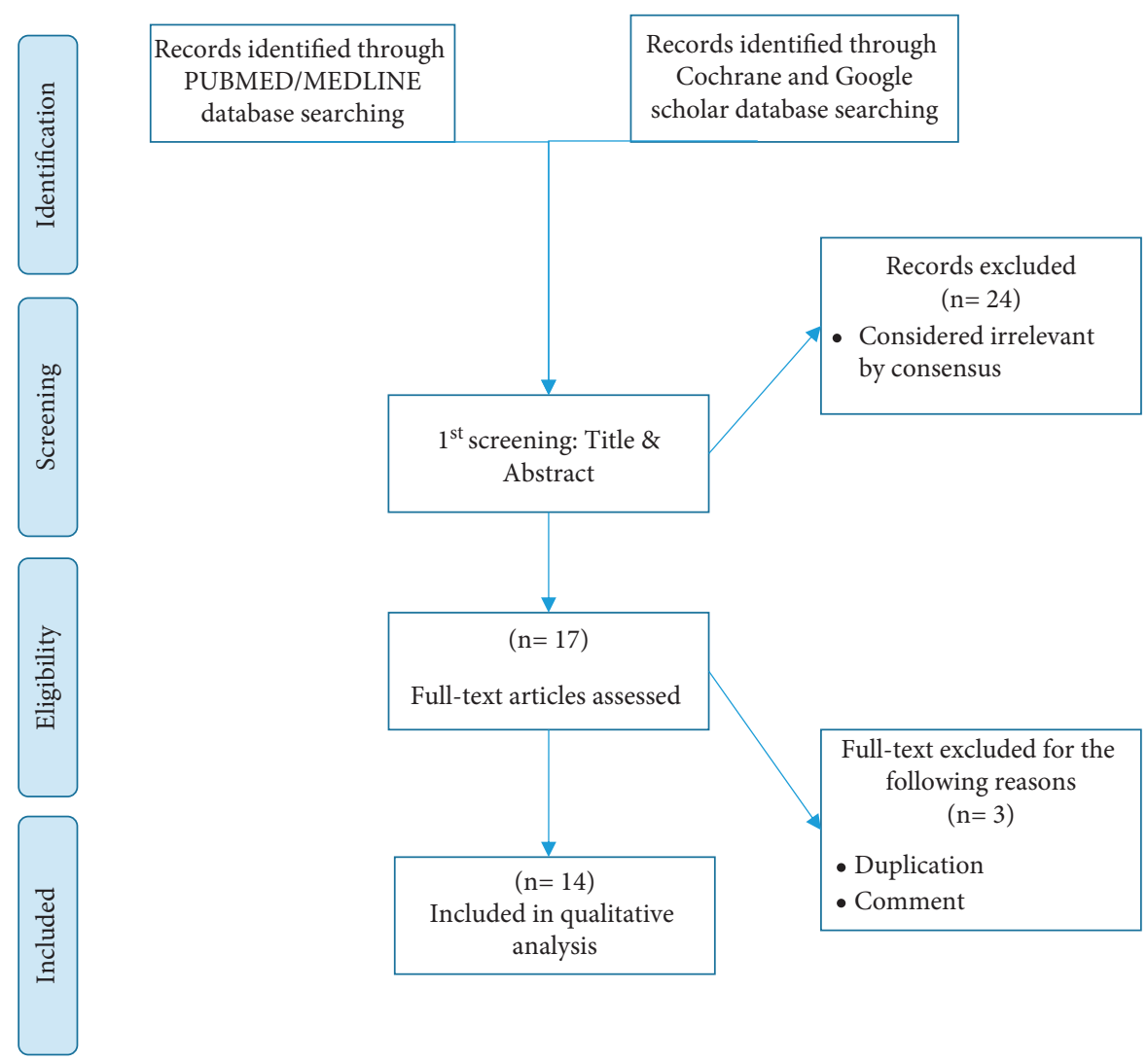

Figure 1: Flowcharts for the studies were identified, displayed, and included in the study.

score that indicated the risk of bias in that study. If eight to eleven positive responses were received, the risk of bias was low; if four to seven questions were answered positive, the risk of bias was moderate; and if fewer than three questions received a positive response, the risk of bias was assessed as high [40]. The assessment was conducted by two qualified investigators (kappa $=0.9$ ). If there were any inconsistencies or ambiguities, the matter was resolved through discussion. If the ambiguities were not cleared up, the third investigator was asked to assist.

\section{Results}

3.1. Screening of $S / M-R$. In the initial search, 43 articles were found, of which 36 articles were obtained by PubMed/ MEDLINE, five articles by Cochrane, and two studies by manual search. Then, after reviewing the title, abstract, and inclusion/exclusion criteria, 17 studies were selected. Finally, based on the full text of the articles, 14 S/M-R [44-57] were eventually included in our study (Figure 1). We collected the S/M-R in three parts: prosthesis, success rate, and ET teeth failure rate. The overall number of studies that were analyzed in selected reviews and therefore included in our study was 118.

3.2. Risk of Bias Assessment. We applied the Assessment of Multiple Systematic Reviews (AMSR2) tool to measure the risk of bias used for various studies. Based on the number of correct responses, the level of bias was reported as high, medium, or low (Table 2). In this study, the risk of bias was moderate [including five S/M-R: [44, 45, 47, 56, 57]] and low [including nine S/M-R: [46, 48-55]]. In addition, $41.5 \%$ of all surveys represented low-risk S/M-R (Table 1). Reliable clinical evidence was expected from S/M-R studies with a low risk of bias.

3.3. Characteristics of Systematic Reviews. General information of each S/M-R is presented in Table 3. They include authors and year of publication, number and type of studies, type of analysis, research period, interventions, outcomes, risk of bias, and main results.

\subsection{General Sample Analysis}

(i) The success rate of prosthetic restorations on ET teeth: In three S/M-R $[44,51,54]$, containing a total number of 22 studies (RCTs [1], in vitro studies [12], clinical trials [6], prospective studies [4], and retrospective studies [1]), the success rate was compared. In one study [44], the five-year success rate for endocrowns and conventional crowns was about $77 \%$ and $94 \%$, respectively. Sedrez-Porto et al. [51] and Ploumaki et al. [54] also reported success rates of $92 \%, 79 \%$, and $66 \%$ for single crowns, and fixed and removable prostheses, respectively. 
TABLE 3: Baseline characteristics of systematic reviews assessing the prosthetic restorations on endodontically treated teeth.

\begin{tabular}{|c|c|c|c|c|c|c|c|c|}
\hline Author (year) & $\begin{array}{l}\text { Types/no. of } \\
\text { studies } \\
\text { included }\end{array}$ & $\begin{array}{l}\text { Method } \\
\text { of } \\
\text { analysis }\end{array}$ & Search period & Interventions & $\begin{array}{l}\text { Overall } \\
\text { number of } \\
\text { samples } \\
\text { (restored } \\
\text { teeth) } \\
\end{array}$ & Outcomes accessed & $\begin{array}{l}\text { Risk of } \\
\text { bias }\end{array}$ & Main results \\
\hline $\begin{array}{l}\text { Al-Dabbagh, } \\
2020[44]\end{array}$ & $\begin{array}{l}3 \text { clinical trial/ } \\
7 \text { in vitro }\end{array}$ & SR/MA & $\begin{array}{l}\text { Up to June } \\
2019\end{array}$ & $\begin{array}{l}\text { Evaluation of survival } \\
\text { and success of } \\
\text { endocrowns in ET } \\
\text { teeth restoration }\end{array}$ & 376 & $\begin{array}{l}\text { Restoration materials, } \\
\text { restoration methods, } \\
\text { survival rate, success } \\
\text { rate, failure rate }\end{array}$ & Moderate & $\begin{array}{l}\text { Endocrowns is a } \\
\text { promising } \\
\text { restorative option } \\
\text { for ET posterior } \\
\text { teeth }\end{array}$ \\
\hline $\begin{array}{l}\text { Girotto et al., } \\
2020 \text { [45] }\end{array}$ & 25 & SR/MA & $\begin{array}{l}\text { Up to Nov } \\
2019\end{array}$ & $\begin{array}{l}\text { Preferences of } \\
\text { dentists and students } \\
\text { in choosing the type } \\
\text { of restoration in ET } \\
\text { teeth }\end{array}$ & 600 & $\begin{array}{l}\text { Type of posts } \\
\text { Prefabricated posts } \\
\text { Cast metal posts }\end{array}$ & Moderate & $\begin{array}{c}\text { Restorative } \\
\text { preferences related } \\
\text { to posts have } \\
\text { changed over time, } \\
\text { from cast posts to } \\
\text { prefabricated ones } \\
\text { or the use of both } \\
\text { posts. They seem to } \\
\text { be influenced by } \\
\text { experience and } \\
\text { postgraduate } \\
\text { training }\end{array}$ \\
\hline $\begin{array}{l}\text { Wang et al., } \\
2019 \text { [46] }\end{array}$ & 4 RCTs & SR/MA & $\begin{array}{l}\text { Up to Jan } \\
2018\end{array}$ & $\begin{array}{l}\text { Fiber posts vs. metal } \\
\text { posts for restoration }\end{array}$ & 223 & $\begin{array}{c}\text { Fiber posts survival } \\
\text { rate } \\
\text { Metal posts survival } \\
\text { rate } \\
\text { Success rates } \\
\text { Post debonding rates } \\
\text { Root fracture rates }\end{array}$ & Low & $\begin{array}{c}\text { Fiber posts } \\
\text { displayed higher } \\
\text { medium-term } \\
\text { overall survival rates } \\
\text { than metal posts } \\
\text { when used to restore } \\
\text { ET teeth with no } \\
\text { more than two } \\
\text { coronal walls } \\
\text { remaining. }\end{array}$ \\
\hline $\begin{array}{l}\text { Naumann } \\
\text { et al., } 2018 \text { [47] }\end{array}$ & $\begin{array}{c}7 \text { RCTs } \\
1 \text { prospective }\end{array}$ & SR & June 2017 & $\begin{array}{l}\text { Postendodontic } \\
\text { treatment using posts } \\
\text { with or without } \\
\text { ferrule }\end{array}$ & 1530 & $\begin{array}{l}\text { Failure rates of post/ } \\
\text { core complexes with or } \\
\text { without ferrule } \\
\text { support tooth and/or } \\
\text { restoration survival }\end{array}$ & Moderate & $\begin{array}{l}\text { Ferrule effect and } \\
\text { maintaining cavity } \\
\text { walls are the } \\
\text { predominant factors } \\
\text { concerning tooth } \\
\text { and restoration } \\
\text { survival of ET teeth }\end{array}$ \\
\hline $\begin{array}{l}\text { Sarkis-Onofre } \\
\text { et al., } 2017 \text { [48] }\end{array}$ & 9 RCTs & SR & 2004 to 2013 & $\begin{array}{c}\text { Influence of the } \\
\text { number of remaining } \\
\text { coronal walls, the use } \\
\text { or disuse of posts, and } \\
\text { their type }\end{array}$ & 1526 & $\begin{array}{c}\text { Post- or crown } \\
\text { cementation } \\
\text { endodontic failure } \\
\text { crown/postfracture } \\
\text { crown dislodgements } \\
\text { postdebonding rates } \\
\text { clinical/radiographic } \\
\text { examination }\end{array}$ & Low & $\begin{array}{l}\text { Should focus on the } \\
\text { maintenance of the } \\
\text { coronal structure }\end{array}$ \\
\hline $\begin{array}{l}\text { Suksaphar } \\
\text { et al., } 2017 \text { [49] }\end{array}$ & $\begin{array}{c}1 \text { RCTs } \\
1 \text { Prospective } \\
1 \\
\text { Retrospective }\end{array}$ & SR & 1980 to 2016 & $\begin{array}{l}\text { Crowns or resin } \\
\text { composite for } \\
\text { posterior teeth } \\
\text { restored }\end{array}$ & 116 & $\begin{array}{l}\text { Survival rate against } \\
\text { fracture }\end{array}$ & Low & $\begin{array}{l}\text { The survival rates } \\
\text { against the fracture } \\
\text { of ET posterior teeth } \\
\text { restored with } \\
\text { crowns or resin } \\
\text { composites were not } \\
\text { significantly } \\
\text { different in the teeth } \\
\text { with minimum to } \\
\text { moderate loss of } \\
\text { tooth structure }\end{array}$ \\
\hline $\begin{array}{l}\text { Sorrentino } \\
\text { et al., } 2016 \text { [50] }\end{array}$ & 4 RCTs & SR & Up to 2015 & $\begin{array}{l}\text { Fiber posts and single } \\
\text { crowns or fixed } \\
\text { dental prostheses for } \\
\text { restoration }\end{array}$ & 117 & $\begin{array}{l}\text { Failure rates of fiber } \\
\text { posts prosthetic } \\
\text { restorations }\end{array}$ & Low & $\begin{array}{l}\text { A correlation } \\
\text { between the failure } \\
\text { rates of fiber posts } \\
\text { and the type of } \\
\text { prosthetic } \\
\text { restorations, just } \\
\text { like SCs and FDPs, } \\
\text { cannot be found to } \\
\text { date }\end{array}$ \\
\hline
\end{tabular}


TABle 3: Continued.

\begin{tabular}{|c|c|c|c|c|c|c|c|c|}
\hline Author (year) & $\begin{array}{l}\text { Types/no. of } \\
\text { studies } \\
\text { included }\end{array}$ & $\begin{array}{l}\text { Method } \\
\text { of } \\
\text { analysis }\end{array}$ & Search period & Interventions & $\begin{array}{l}\text { Overall } \\
\text { number of } \\
\text { samples } \\
\text { (restored } \\
\text { teeth) }\end{array}$ & Outcomes accessed & $\begin{array}{l}\text { Risk of } \\
\text { bias }\end{array}$ & Main results \\
\hline $\begin{array}{l}\text { Sedrez-Porto } \\
\text { et al., } 2016[51]\end{array}$ & $\begin{array}{l}3 \text { Clinical trial } \\
5 \text { In vitro }\end{array}$ & SR/M-A & $\begin{array}{l}\text { Up to } \\
\text { February } \\
2016\end{array}$ & $\begin{array}{c}\text { Endocrown } \\
\text { compared to } \\
\text { conventional } \\
\text { treatments } \\
\text { (intraradicular posts, } \\
\text { direct composite } \\
\text { resin, and inlay/ } \\
\text { onlay). For } \\
\text { restorations }\end{array}$ & - & $\begin{array}{l}\text { Fracture strength } \\
\text { endocrown } \\
\text { restorations } \\
\text { conventional } \\
\text { restorations }\end{array}$ & Low & $\begin{array}{l}\text { Endocrowns may } \\
\text { perform similarly or } \\
\text { better than the } \\
\text { conventional } \\
\text { treatments using } \\
\text { intraarticular posts, } \\
\text { direct composite } \\
\text { resin, or inlay/onlay } \\
\text { restorations }\end{array}$ \\
\hline $\begin{array}{l}\text { Sequeira- } \\
\text { Byron et al., } \\
2015[52]\end{array}$ & I RCTs & SR/MA & $\begin{array}{l}\text { Up to March } \\
2015\end{array}$ & $\begin{array}{l}\text { Single crowns versus } \\
\text { conventional fillings }\end{array}$ & - & $\begin{array}{c}\text { Catastrophic failure of } \\
\text { restoration, } \\
\text { noncatastrophic } \\
\text { failure of restoration, } \\
\text { noncatastrophic } \\
\text { failure of post }\end{array}$ & Low & $\begin{array}{l}\text { There is insufficient } \\
\text { evidence to assess } \\
\text { the effects of crowns } \\
\text { compared to } \\
\text { conventional fillings } \\
\text { to restore root-filled } \\
\text { teeth }\end{array}$ \\
\hline $\begin{array}{l}\text { Figueiredo } \\
\text { et al., } 2015 \text { [53] }\end{array}$ & $\begin{array}{l}7 \text { RCTs } \\
7 \text { Cohort }\end{array}$ & SR/MA & $\begin{array}{l}\text { Up to January } \\
2014\end{array}$ & $\begin{array}{l}\text { Incidence rate related } \\
\text { to the use of metal } \\
\text { posts was higher than } \\
\text { that of fiber posts }\end{array}$ & 3202 & $\begin{array}{l}\text { Metal-based posts } \\
\text { survival rate fiber- } \\
\text { reinforced posts } \\
\text { survival rate } \\
\text { catastrophic failures }\end{array}$ & Low & $\begin{array}{l}\text { Results did not show } \\
\text { significant } \\
\text { differences for root } \\
\text { fracture incidence } \\
\text { between metal and } \\
\text { fiber posts }\end{array}$ \\
\hline $\begin{array}{l}\text { Ploumaki et al., } \\
2013 \text { [54] }\end{array}$ & $\begin{array}{c}1 \text { RCTs } \\
3 \text { Prospective }\end{array}$ & SR/MA & $\begin{array}{l}\text { Up to June } \\
2012\end{array}$ & $\begin{array}{l}\text { The success rates of } \\
\text { prosthetic } \\
\text { restorations on } \\
\text { endodontically } \\
\text { treated teeth }\end{array}$ & 1206 & $\begin{array}{l}\text { Success rate of single } \\
\text { crowns success rates of } \\
\text { crowns over cast post } \\
\text { and core success rates } \\
\text { of crowns over } \\
\text { prefabricated posts }\end{array}$ & Low & $\begin{array}{l}\text { The results of this } \\
\text { systematic review } \\
\text { should be } \\
\text { interpreted with } \\
\text { caution }\end{array}$ \\
\hline $\begin{array}{l}\text { Bolla et al., } \\
2007 \text { [55] }\end{array}$ & 2 RCTs & SR/MA & $\begin{array}{l}\text { CENTRAL to } \\
2005 \\
\text { MEDLINE to } \\
\text { September } \\
\text { 2005/Scopus } \\
\text { to December } \\
2004 \\
\text { EMBASE to } \\
\text { D } \\
\text { es } 2004\end{array}$ & $\begin{array}{l}\text { Root canal posts for } \\
\text { the restoration }\end{array}$ & 317 & $\begin{array}{l}\text { Loss of retention, } \\
\text { postfracture root } \\
\text { fracture }\end{array}$ & Low & $\begin{array}{l}\text { It is not specified } \\
\text { which type of post } \\
\text { and core system } \\
\text { should be used } \\
\text { when two or three } \\
\text { dentine walls } \\
\text { remain }\end{array}$ \\
\hline $\begin{array}{l}\text { Stavropoulou } \\
\text { and Koidis, } \\
2007[56]\end{array}$ & 10 RCTs & SR/MA & 1960 to 2006 & $\begin{array}{l}\text { Placement of a crown } \\
\text { is associated with } \\
\text { improved (long term) } \\
\text { survival of root canal } \\
\text { treated teeth }\end{array}$ & - & $\begin{array}{l}\text { Survival of RCT } \\
\text { restored with crowns } \\
\text { survival of RCT with } \\
\text { direct restorations }\end{array}$ & Moderate & $\begin{array}{l}\text { RCTs restored with } \\
\text { crowns show an } \\
\text { acceptable long- } \\
\text { term survival of } 10 \\
\text { years, while direct } \\
\text { restorations have an } \\
\text { excellent survival } \\
\text { only for a short } \\
\text { period. }\end{array}$ \\
\hline $\begin{array}{l}\text { Heydecke and } \\
\text { Peters } 2002 \\
{[57]}\end{array}$ & $\begin{array}{l}10 \text { Clinical } \\
\text { trial } \\
6 \text { In vitro }\end{array}$ & SR/MA & $\begin{array}{l}1995 \text { and } \\
2000\end{array}$ & $\begin{array}{l}\text { Single-rooted teeth } \\
\text { with cast or direct } \\
\text { posts and cores }\end{array}$ & 1758 & $\begin{array}{c}\text { Load-to-failure } \\
\text { Cast post } \\
\text { and core failure } \\
\text { Direct post and core } \\
\text { failure }\end{array}$ & Moderate & $\begin{array}{c}\text { No significant } \\
\text { difference between } \\
\text { cast and direct posts } \\
\text { and cores }\end{array}$ \\
\hline
\end{tabular}

SR: systematic review;/MA: meta-analysis; RCTs: randomized clinical trials. 
(ii) The success rate of single crowns in ET teeth restored with or without posts: Three S/M-R $[45,48,54]$ including 34 studies were surveyed. According to Ploumaki et al. [54], the success rates of single crowns on teeth without posts, with posts, with cast post and cores, and with prefabricated posts were 94\%, 92\%, 93\%, and 94\%, respectively. Sarkis-Onofre et al. [48] reported the success rate of elastic posts from 71.8 to $100 \%$. Girotto et al. [45] stated that the most frequently used posts were firstly prefabricated and secondly metal posts with rates of $45.8 \%$ and $16.7 \%$, respectively. They mentioned time and training as factors affecting the decision of choosing prefabricated or metal posts.

(iii) Survival rate of single crowns on ET teeth: eight S/M-R articles $[44,46-49,53,56,57]$, listed in Table 3, including 48 RCT, 13 in vitro, 10 clinical trials, and 2 prospective studies, provided information on survival. Based on the study performed by Al-Dabbagh [44], the overall 5-year survival rates for endocrowns and conventional crowns were $91.4 \%$ and $98.3 \%$, respectively. In the study performed by Suksaphar et al. [49], the survival rate of crowns was $94 \%$, and the composite resin survival rate was $91 \%$. In addition, according to the study of Stavropoulou and Koidis [56], the 10-year survival rates for crowns and direct restorations were $81 \%$ and $63 \%$, respectively. Suksaphar et al. [49] reported that the survival rate of composite resin or crowns against fracture was nearly the same. Wang et al. [46] concluded that the survival rate of fiber posts was significantly higher than metal posts. They found that for root treatment with more than two crowned walls, the medium-term survival rate of fiber posts was higher than metal posts. Figueiredo et al. [53] reported that the survival rates of metal posts and fiber posts were $90 \%$ and $83.9 \%$, respectively. In addition, the survival rate of cast post and cores in the study by Heydecke and Peters [57] ranged from $87.2 \%$ to $88.1 \%$. Naumann et al. [47] also stated in their study that ferrule increases the survival rate of endodontic-treated teeth by preserving cavity walls. According to Sarkis-Onofre et al. [48], teeth without ferrule also showed a higher variation in the survival rate $(0 \%-97 \%)$ compared to teeth with ferrule.

(iv) Failure rate: The six S/M-R [46, 50, 51, 53, 54, 57] listed in Table 3 contained 48 studies including RTCs [14], in vitro studies [11], clinical trials [13], prospective studies [3], and cohorts [7]. They reported failure rates in their systematic reviews. According to Wang et al. [46], the success rate, postdebonding rate, or root fracture rate between fiber posts and metal posts were not significantly different. Moreover, according to the study by Figueiredo et al. [53], the rate of root fractures in metal and fiber posts was similar. Furthermore, the rate of root fractures in prefabricated metal posts and carbon fiber was twice as high as that of metal posts and fiberglass. In the review performed by Heydecke and Peters [57], the failure rate between direct posts and direct post and cores was not significantly different. According to the study performed by Sorrentino et al. [50], the most frequent failures in single crowns and fixed prostheses were caused by the separation of the fiber post, lack of single crown retention, and marginal clefts. In Sedrez-Porto et al. [51] study, the rate of failure in endocrowns was reported higher than that of conventional methods. Ploumaki et al. [54] also reported postdebonding as the most common cause of failure.

\section{Discussion}

Due to controversy among studies on the success rate of endodontically treated teeth, the purpose of this umbrella review was to compare the clinical evidence for the success and failure rates of restorations in endodontically treated teeth. Targets included fixed/removable prostheses and posts and the rate of success and failure in them. Data from 14 systematic reviews [44-57], which included 118 studies and more than 10971 samples altogether, were categorized based on the type of restoration.

In 22 of the 118 studies, successful single crowns on ET teeth were reported exclusively [58-60]. Furthermore, in 34 studies, the success rate of single crowns on ET teeth was compared with or without posts. The five-year success rate of the endo-crown system was $94 \%[1,3]$. Eventually, the survival rate of ET teeth was associated with the remaining crown structures and the type of restorative material. Both of these play an important role in increasing the chance of long-term dental survival. Based on clinical studies, a single crown is the best treatment for ET teeth. However, highquality clinical evidence on this subject is required due to the limited number of data available.

Within the systematic review studies, the results from four studies were about fixed and removable prostheses. Thirty-four studies reported postrestoration success. The success rate for ET teeth [58] after six years was $94-92 \%$. Furthermore, the success rate for fixed and removable prostheses was $78 \%$ and $66 \%$, respectively. In general, single crowns perform better than other prosthetic restorations $[28,61]$. This is because the dental stresses in fixed and removable dentures are more than single crowns [28]. Besides, removable dentures should also be reinforced with posts $[13,28]$. According to the results of the review studies, the success rate for prefabricated posts was higher than cast/ core posts. Clinically, however, dentists engage in cast/core posts when dealing with moderate to high tissue loss. Findings from various studies show that nonmetallic fiber posts work better than metal posts $[55,62,63]$. However, the overall evidence in this area is relatively weak and should be interpreted more accurately.

One of the tools to assess the quality and bias of studies is the AMSTAR tool, which is designed based on responses to a standard set of questions. It is necessary to correctly 
interpret the information to use quality measurement tools and determine the S/M-R proficiency level. However, during this assessment, the Funding Sources parameter in the text was not indicated. Therefore, more attention to this issue is recommended in articles. Despite the limitations of this study, we evaluated the results of several systematic reviews comprehensively and tried to eliminate some controversies among their results. Nevertheless, more investigation is recommended in this regard to draw a more reliable conclusion for clinicians.

\section{Conclusion}

It appears that one of the most reliable ways to restore ET teeth is to apply single crowns and endocrowns. However, more consistent studies are required to present the reported findings more confidently. Even considering the potential for bias, the level of evidence available for the use of this clinical method is high.

\section{Conflicts of Interest}

The authors declare no conflicts of interest.

\section{References}

[1] M. K. Georgopoulou, A. P. Spanaki-Voreadi, N. Pantazis, and E. G. Kontakiotis, "Frequency and distribution of root filled teeth and apical periodontitis in a Greek population," International Endodontic Journal, vol. 38, no. 2, pp. 105-111, 2005.

[2] L. B. Peters, J. A. Lindeboom, M. E. Elst, and P. R. Wesselink, "Prevalence of apical periodontitis relative to endodontic treatment in an adult Dutch population: a repeated crosssectional study," Oral Surgery, Oral Medicine, Oral Pathology, Oral Radiology \& Endodontics, vol. 111, no. 4, pp. 523-528, 2011.

[3] M. A. Al-Omari, A. Hazaa, and F. Haddad, "Frequency and distribution of root filled teeth and apical periodontitis in a Jordanian subpopulation," Oral Surgery, Oral Medicine, Oral Pathology, Oral Radiology \& Endodontics, vol. 111, no. 1, pp. e59-e65, 2011.

[4] N. Gencoglu, F. N. Pekiner, B. Gumru, and D. Helvacioglu, "Periapical status and quality of root fillings and coronal restorations in an adult Turkish subpopulation," European Journal of Dermatology, vol. 4, no. 1, pp. 017-022, 2010.

[5] N. N. Dugas, H. P. Lawrence, P. E. Teplitsky, M. J. Pharoah, and S. Friedman, "Periapical health and treatment quality assessment of root-filled teeth in two Canadian populations," International Endodontic Journal, vol. 36, no. 3, pp. 181-192, 2003.

[6] L.-L. Kirkevang, D. Orstavik, P. Horsted-Bindslev, and A. Wenzel, "Periapical status and quality of root fillings and coronal restorations in a Danish population," International Endodontic Journal, vol. 33, no. 6, pp. 509-515, 2000.

[7] R. Weiger, S. Hitzler, G. Hermle, and C. Lost, "Periapical status, quality of root canal fillings and estimated endodontic treatment needs in an urban German population," Dental Traumatology, vol. 13, no. 2, pp. 69-74, 1997.

[8] M. Trope and H. L. Ray Jr, "Resistance to fracture of endodontically treated roots," Oral Surgery, Oral Medicine, Oral Pathology, vol. 73, no. 1, pp. 99-102, 1992.
[9] E. S. Reeh, H. H. Messer, and W. H. Douglas, "Reduction in tooth stiffness as a result of endodontic and restorative procedures," Journal of Endodontics, vol. 15, no. 11, pp. 512-516, 1989.

[10] L. W. M. Van der Sluis, M.-K. Wu, and P. R. Wesselink, "The efficacy of ultrasonic irrigation to remove artificially placed dentine debris from human root canals prepared using instruments of varying taper," International Endodontic Journal, vol. 38, no. 10, pp. 764-768, 2005.

[11] T. Y. Huang, K. Gulabivala, and Y. L. Ng, "A bio-molecular film ex-vivo model to evaluate the influence of canal dimensions and irrigation variables on the efficacy of irrigation," International Endodontic Journal, vol. 41, no. 1, pp. 60-71, 2008.

[12] L. H. Berman and K. M. Hargreaves, Cohen's Pathways of the Pulp Expert Consult, Elsevier Health Sciences, Amsterdam, Netherlands, 2015.

[13] I. Peroz, F. Blankenstein, K. P. Lange, and M. Naumann, "Restoring endodontically treated teeth with posts and cores-a review," Quintessence International, vol. 36, no. 9, pp. 737-46, 2005.

[14] C. J. Goodacre and K. J. Spolnik, "The prosthodontic management of endodontically treated teeth: a literature review. Part I. Success and failure data, treatment concepts," Journal of Prosthodontics, vol. 3, no. 4, pp. 243-250, 1994.

[15] R. Schwartz and J. Robbins, "Post placement and restoration of endodontically treated teeth: a literature review," Journal of Endodontics, vol. 30, no. 5, pp. 289-301, 2004.

[16] M. Chieruzzi, M. Rallini, S. Pagano et al., "Mechanical effect of static loading on endodontically treated teeth restored with fiberreinforced posts," Journal of Biomedical Materials Research Part B: Applied Biomaterials, vol. 102, no. 2, pp. 384-394, 2014.

[17] M. Torabinejad, P. Anderson, J. Bader et al., "Outcomes of root canal treatment and restoration, implant-supported single crowns, fixed partial dentures, and extraction without replacement: a systematic review," The Journal of Prosthetic Dentistry, vol. 98, no. 4, pp. 285-311, 2007.

[18] M. K. Iqbal and S. Kim, "For teeth requiring endodontic treatment, what are the differences in outcomes of restored endodontically treated teeth compared to implant-supported restorations?" The International Journal of Oral \& Maxillofacial Implants, vol. 22, no. 7, 2007.

[19] Y.-L. Ng, V. Mann, and K. Gulabivala, "Tooth survival following non-surgical root canal treatment: a systematic review of the literature," International Endodontic Journal, vol. 43, no. 3, pp. 171-189, 2010.

[20] R. Salehrabi and I. Rotstein, "Endodontic treatment outcomes in a large patient population in the USA: an epidemiological study," Journal of Endodontics, vol. 30, no. 12, pp. 846-850, 2004.

[21] C. L. Basmadjian-Charles, P. Farge, D. M. Bourgeois, and T. Lebrun, "Factors influencing the long-term results of endodontic treatment: a review of the literature," International Dental Journal, vol. 52, no. 2, pp. 81-86, 2002.

[22] U. Sjogren, B. Hagglund, G. Sundqvist, and K. Wing, "Factors affecting the long-term results of endodontic treatment," Journal of Endodontics, vol. 16, no. 10, pp. 498-504, 1990.

[23] K. Kojima, K. Inamoto, K. Nagamatsu et al., "Success rate of endodontic treatment of teeth with vital and nonvital pulps. A meta-analysis," Oral Surgery, Oral Medicine, Oral Pathology, Oral Radiology \& Endodontics, vol. 97, no. 1, pp. 95-99, 2004.

[24] D. Ørstavik, V. Qvist, and K. Stoltze, “A multivariate analysis of the outcome of endodontic treatment," European Journal of Oral Sciences, vol. 112, no. 3, pp. 224-230, 2004. 
[25] D. B. Swartz, A. E. Skidmore, and J. A. Griffin Jr, "Twenty years of endodontic success and failure," Journal of Endodontics, vol. 9, no. 5, pp. 198-202, 1983.

[26] Y.-L. Ng, V. Mann, and K. Gulabivala, "A prospective study of the factors affecting outcomes of non-surgical root canal treatment: part 2: tooth survival," International Endodontic Journal, vol. 44, no. 7, pp. 610-625, 2011.

[27] M. K. Iqbal, A. A. Johansson, R. F. Akeel, A. Bergenholtz, and R. Omar, "A retrospective analysis of factors associated with the periapical status of restored, endodontically treated teeth," The International Journal of Prosthodontics, vol. 16, no. 1, pp. 31-8, 2003.

[28] J. A. Sorensen and J. T. Martinoff, "Endodontically treated teeth as abutments," The Journal of Prosthetic Dentistry, vol. 53, no. 5, pp. 631-636, 1985.

[29] R. Meeuwissen and S. Eschen, "Twenty years of endodontic treatment," Journal of Endodontics, vol. 9, no. 9, pp. 390-393, 1983.

[30] Y. Zadik, V. Sandler, R. Bechor, and R. Salehrabi, “Analysis of factors related to extraction of endodontically treated teeth," Oral Surgery, Oral Medicine, Oral Pathology, Oral Radiology \& Endodontics, vol. 106, no. 5, pp. e31-e35, 2008.

[31] T. Dammaschke, D. Steven, M. Kaup, and K. Ott, "Long-term survival of root-canal-treated teeth: a retrospective study over 10 years," Journal of Endodontics, vol. 29, no. 10, pp. 638-643, 2003.

[32] S.-O. Hedlund, N. G. Johansson, and G. Sjögren, "A retrospective study of pre-fabricated carbon fibre root canal posts," Journal of Oral Rehabilitation, vol. 30, no. 10, pp. 1036-1040, 2003.

[33] S. Segerström, J. Astbäck, and K. D. Ekstrand, "A retrospective long term study of teeth restored with prefabricated carbon fiber reinforced epoxy resin posts," Swedish Dental Journal, vol. 30, no. 1, pp. 1-8, 2006.

[34] A. G. B. Mentink, N. H. J. Creugers, R. Meeuwissen, P. J. B. Leempoel, and A. F. Käyser, "Clinical performance of different post and core systems-results of a pilot study," Journal of Oral Rehabilitation, vol. 20, no. 6, pp. 577-584, 1993.

[35] G. E. Salvi, B. E. Siegrist Guldener, T. Amstad, A. Joss, and N. P. Lang, "Clinical evaluation of root filled teeth restored with or without post-and-core systems in a specialist practice setting," International Endodontic Journal, vol. 40, no. 3, pp. 209-215, 2007.

[36] C. Sathorn, P. Parashos, and H. H. Messer, "Effectiveness of single-versus multiple-visit endodontic treatment of teeth with apical periodontitis: a systematic review and metaanalysis," International Endodontic Journal, vol. 38, no. 6, pp. 347-355, 2005.

[37] T. Naito, "Single or multiple visits for endodontic treatment?" Evidence-Based Dentistry, vol. 9, no. 1, Article ID 24, 2008.

[38] Y. Su, C. Wang, and L. Ye, "Healing rate and post-obturation pain of single-versus multiple-visit endodontic treatment for infected root canals: a systematic review," Journal of Endodontics, vol. 37, no. 2, pp. 125-132, 2011.

[39] L. Figini, G. Lodi, F. Gorni, and M. Gagliani, "Single versus multiple visits for endodontic treatment of permanent teeth: a Cochrane systematic review," Journal of Endodontics, vol. 34, no. 9, pp. 1041-1047, 2008.

[40] V. Silva, A. J. Grande, A. P. V. d. Carvalho, A. L. C. Martimbianco, and R. Riera, "Overview of systematic reviews-a new type of study. Part II," Sao Paulo Medical Journal, vol. 133, no. 3, pp. 206-217, 2014.
[41] D. L. Sackett, W. M. Rosenberg, J. A. Gray, R. B. Haynes, and W. S. Richardson, "Evidence based medicine: what it is and what it isn't," BMJ, vol. 312, pp. 71-2, 1996.

[42] S. Asar, S. Jalalpour, F. Ayoubi, M. Rahmani, and M. Rezaeian, "PRISMA; preferred reporting items for systematic reviews and meta-analyses," Journal of Rafsanjan University of Medical Sciences, vol. 15, no. 1, pp. 68-80, 2016.

[43] B. J. Shea, J. M. Grimshaw, G. A. Wells et al., "Development of AMSTAR: a measurement tool to assess the methodological quality of systematic reviews," BMC Medical Research Methodology, vol. 7, no. 1, pp. 10-17, 2007.

[44] R. A. Al-Dabbagh, "Survival and success of endocrowns: a systematic review and meta-analysis," The Journal of Prosthetic Dentistry, vol. 125, no. 3, pp. e1-415, 2021.

[45] L. P. S. Girotto, L. Dotto, G. K. R. Pereira, A. Bacchi, and R. Sarkis-Onofre, "Restorative preferences and choices of dentists and students for restoring endodontically treated teeth: a systematic review of survey studies," The Journal of Prosthetic Dentistry, vol. 126, 2020.

[46] X. Wang, X. Shu, Y. Zhang, B. Yang, Y. Jian, and K. Zhao, "Evaluation of fiber posts vs. metal posts for restoring severely damaged endodontically treated teeth: a systematic review and meta-analysis," Quintessence International, vol. 50, no. 1, pp. 8-20, 2019.

[47] M. Naumann, M. Schmitter, R. Frankenberger, and G. Krastl, "“Ferrule comes first. Post is second!" fake news and alternative facts? A systematic review," Journal of Endodontics, vol. 44, no. 2, pp. 212-219, 2018.

[48] R. Sarkis-Onofre, D. Fergusson, M. S. Cenci, D. Moher, and T. Pereira-Cenci, "Performance of post-retained single crowns: a systematic review of related risk factors," Journal of Endodontics, vol. 43, no. 2, pp. 175-183, 2017.

[49] W. Suksaphar, D. Banomyong, T. Jirathanyanatt, and Y. Ngoenwiwatkul, "Survival rates against fracture of endodontically treated posterior teeth restored with full-coverage crowns or resin composite restorations: a systematic review," Restorative Dentistry \& Endodontics, vol. 42, no. 3, pp. 157167, 2017.

[50] R. Sorrentino, M. I. Di Mauro, M. Ferrari, R. Leone, and F. Zarone, "Complications of endodontically treated teeth restored with fiber posts and single crowns or fixed dental prostheses-a systematic review," Clinical Oral Investigations, vol. 20, no. 7, pp. 1449-1457, 2016.

[51] J. A. Sedrez-Porto, W. L. d. O. d. Rosa, A. F. da Silva, E. A. Münchow, and T. Pereira-Cenci, "Endocrown restorations: a systematic review and meta-analysis," Journal of Dentistry, vol. 52, pp. 8-14, 2016.

[52] P. Sequeira-Byron, Z. Fedorowicz, B. Carter, M. Nasser, and E. F. Alrowaili, "Single crowns versus conventional fillings for the restoration of root-filled teeth," Cochrane Database of Systematic Reviews, vol. 16, no. 9, 2015.

[53] F. E. D. Figueiredo, P. R. S. Martins-Filho, and A. L. Faria-eSilva, "Do metal post-retained restorations result in more root fractures than fiber post-retained restorations? A systematic review and meta-analysis," Journal of Endodontics, vol. 41, no. 3, pp. 309-316, 2015.

[54] A. Ploumaki, A. Bilkhair, T. Tuna, S. Stampf, and J. R. Strub, "Success rates of prosthetic restorations on endodontically treated teeth; a systematic review after 6 years," Journal of Oral Rehabilitation, vol. 40, no. 8, pp. 618-630, 2013.

[55] M. Bolla, M. Muller-Bolla, C. Borg, L. Lupi-Pegurier, O. Laplanche, and E. Leforestier, "Root canal posts for the restoration of root filled teeth," Cochrane Database of Systematic Reviews, vol. 24, no. 1, 2007. 
[56] A. F. Stavropoulou and P. T. Koidis, "A systematic review of single crowns on endodontically treated teeth," Journal of Dentistry, vol. 35, no. 10, pp. 761-767, 2007.

[57] G. Heydecke and M. C. Peters, "The restoration of endodontically treated, single-rooted teeth with cast or direct posts and cores: a systematic review," The Journal of Prosthetic Dentistry, vol. 87, no. 4, pp. 380-386, 2002.

[58] M. Balkenhol, B. Wöstmann, C. Rein, and P. Ferger, "Survival time of cast post and cores: a 10-year retrospective study," Journal of Dentistry, vol. 35, no. 1, pp. 50-58, 2007.

[59] B. Bergman, P. Lundquist, U. Sjo"gren, and G. r. Sundquist, "Restorative and endodontic results after treatment with cast posts and cores," The Journal of Prosthetic Dentistry, vol. 61, no. 1, pp. 10-15, 1989.

[60] S. Ellner, T. Bergendal, and B. Bergman, "Four post-and-core combinations as abutments for fixed single crowns: a prospective up to 10-year study," The International Journal of Prosthodontics, vol. 16, no. 3, pp. 249-54, 2003.

[61] D. J. Caplan and J. A. Weintraub, "Factors related to loss of root canal filled teeth," Journal of Public Health Dentistry, vol. 57, no. 1, pp. 31-39, 1997.

[62] M. C. Cagidiaco, C. Goracci, F. Garcia-Godoy, and M. Ferrari, "Clinical studies of fiber posts: a literature review," The International Journal of Prosthodontics, vol. 21, no. 4, pp. 32836, 2008.

[63] C. J. Goodacre, "Carbon fiber posts may have fewer failures than metal posts," Journal of Evidence-Based Dental Practice, vol. 10, no. 1, pp. 32-34, 2010. 